\title{
Evaluation of Tropical Legume Cover Crops for Copper Use Efficiency
}

\author{
Nand Kumar Fageria1, Virupax Chanabasappa Baligar ${ }^{2}$ \\ ${ }^{1}$ National Rice and Bean Research Center of EMBRAPA (Empresa Brasileira de Pesquisa Agropecuária), \\ Santo Antônio de Goiás, Brazil \\ ${ }^{2}$ Beltsville Agricultural Research Center, USDA-ARS, Beltsville, USA \\ Email: Nand.fageria@embrapa.br
}

Received 31 January 2014; revised 8 March 2014; accepted 20 March 2014

Copyright (C) 2014 by authors and Scientific Research Publishing Inc.

This work is licensed under the Creative Commons Attribution International License (CC BY).

http://creativecommons.org/licenses/by/4.0/

(c) () Open Access

\begin{abstract}
Cover crops are important components of cropping systems due to their role in improving soil quality. Lack of adequate levels of soil micronutrients prevents the success of cover crops in highly weathered tropical soils. A greenhouse experiment was conducted with the objective to evaluate copper use efficiency of nine tropical legume cover crops. The copper levels used were 0, 5, 10 and

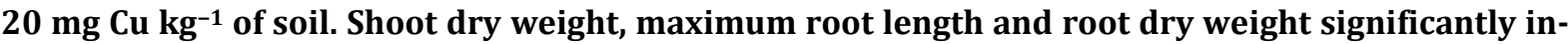
creased in a quadratic fashion with increasing soil Cu levels in the range of 0 to $20 \mathrm{mg} \mathrm{kg}^{-1} \mathrm{soil}$. Cu $x$ cover crops interactions for shoot dry weight, root dry weight, maximum root length and contribution of root to the total dry weight were significant, indicating different responses of cover crops with the variation in soil Cu levels. Overall, maximum shoot dry weight was obtained with the application of $13 \mathrm{mg} \mathrm{Cu} \mathrm{kg-1}^{-1}$ Similarly, maximum root dry weight and maximum root length were obtained with the application of 12 and $14 \mathrm{mg} \mathrm{Cu} \mathrm{kg}^{-1}$ of soil. Root dry weight and maximum root length were significantly and positively related to shoot dry weight, indicating that a vigorous root system is important for improving productivity of cover crops grown on Brazilian Oxisols, especially where deficiency of micronutrients such as $\mathrm{Cu}$ exists. The Cu concentration in the plant tissue decreased in a quadratic fashion whereas, $\mathrm{Cu}$ uptake increased with increasing $\mathrm{Cu}$ application rate from 0 to $20 \mathrm{mg} \mathrm{kg}^{-1}$ soil. There was a significant variation observed in Cu use efficiency among cover crop species. Increasing applied $\mathrm{Cu}$ levels significantly increased soil pH and Mehlich 1 extractable soil $\mathrm{Cu}, \mathrm{Zn}, \mathrm{Mn}$ and $\mathrm{Fe}$ concentrations in the soil solution.
\end{abstract}

\section{Keywords}

Root Length; Root and Shoot Dry Weight; Specific Root Length; Cu Use Efficiency 


\section{Introduction}

Cover crops in tropical highly weathered acidic infertile soils are important components of cropping systems due to their role in improving soil physical, chemical and biological soil quality parameters [1]. In addition to improving soil quality, cover crops also control diseases, insects and weeds and control soil erosion [2]. Cover crops absorb $\mathrm{NO}_{3}-\mathrm{N}$ when planted before main crop and thereby reducing leaching of nitrogen from the soil-plant system. In tropical regions plantation crops are planted with wide spacing and often situated on erodible and steep slope land. Quick growing cover crops before or during early stages of plantation establishment and during rehabilitation stages of older plantations could increase the soil vegetative cover thereby reducing the impact of rain drops that leads to soil erosion and nutrient losses as well as suppressing of weeds [2]. Cover crops can be legumes and non-legumes. However, legumes are superior cover crops compared with non-leguminous crops because they fix atmospheric nitrogen. Considerable variation in $\mathrm{N}$ fixation can occur, even among legume species [2]. A cover crop that is agronomically attractive and economically viable should have some important characteristics. These properties are fast growing for easy adjustment in the cropping system, to produce sufficient dry matter residues to ameliorate soil physical, chemical and biological properties, to fix adequate $\mathrm{N}$ and require minimum cultural practices during growth period to be relatively more economical.

Micronutrient deficiencies, including copper, have been reported in Brazilian Oxisols [3] [4]. Nearly 70\% to $80 \%$ of Cerrado Oxsols are deficient in $\mathrm{Zn}, \mathrm{Cu}$, or $\mathrm{Mn}$ [5]. Micronutrient deficiencies in crop plants are widespread because of 1) increased micronutrient demands from intensive cropping practices and adaptation of high yielding cultivars which may have higher micronutrient demand; 2) enhanced production of crops on marginal soils that contain low levels of essential nutrients; 3) increased use of high analysis fertilizers with low amounts of micronutrients; 4) decreased use of animal manures, composts, and crop residues; 5) use of many soils that are inherently low in micronutrient reserves; and 6) involvement of natural and anthropogenic factors that limit adequate supplies and create element imbalances [6]. Fageria and Baligar [7] reported that cereals and legumes grown on Oxisols responded significantly to macro and micronutrients fertilization. A paucity of data exits for response of cover crops to micronutrient fertilization in acidic soils such as Oxisol. The objectives of this study were to 1) determine cover crops responses to copper fertilization; 2) evaluate applied $\mathrm{Cu}$ on concentrations, uptake and use efficiency of $\mathrm{Cu}$ in cover crops; and 3) evaluate the soil applied $\mathrm{Cu}$ on soil pH and Mehlich 1 extractable $\mathrm{Cu}, \mathrm{Zn}$, Fe and $\mathrm{Mn}$.

\section{Materials and Methods}

A greenhouse experiment was conducted to determine copper requirements of nine tropical legume crops. The soil used in the experiment was an Oxisol whose chemical and physical properties were: pH 5.0, Ca 0.8 cmolc $\mathrm{kg}^{-1}$, Mg 0.7 cmolc kg ${ }^{-1}$ K $18 \mathrm{mg} \mathrm{kg}^{-1}$, P $0.5 \mathrm{mg} \mathrm{kg}^{-1}$, S $4.2 \mathrm{mg} \mathrm{kg}^{-1}$, Zn $1.4 \mathrm{mg} \mathrm{kg}{ }^{-1}$, Cu $1.2 \mathrm{mg} \mathrm{kg}^{-1}$, B 0.14 $\mathrm{mg} \mathrm{kg}^{-1}$, Fe $33.6 \mathrm{mg} \mathrm{kg}^{-1}$, Mn $5.8 \mathrm{mg} \mathrm{kg}^{-1}$, Mo $0.08 \mathrm{mg} \mathrm{kg}^{-1}$ and organic matter $15 \mathrm{~g} \mathrm{~kg}^{-1}$. Soil textural analysis was clay $260 \mathrm{~g} \mathrm{~kg}^{-1}$, silt $70 \mathrm{~g} \mathrm{~kg}^{-1}$ and sand $670 \mathrm{~g} \mathrm{~kg}^{-1}$. Soil analysis methods used in this study are described in a soil analysis manual published by EMBRAPA [8].

Cover crops used are listed in Table 1. Copper levels used were $0,5,10$ and $20 \mathrm{mg} \mathrm{kg}^{-1}$ of soil. The Cu was applied as copper sulfate (24\% Cu). Basic fertilizer rates used were $\mathrm{N} 200 \mathrm{mg} \mathrm{kg}^{-1}$, P $200 \mathrm{mg} \mathrm{kg}^{-1}$ and K 200 $\mathrm{mg} \mathrm{kg}{ }^{-1}$. Nitrogen was applied with urea, $\mathrm{P}$ with triple superphosphate and $\mathrm{K}$ with potassium chloride. One $\mathrm{g}$ dolomitic lime was also applied six weeks before sowing the seeds of cover crops. Lime and nutrients were thoroughly mixed with soil and soils were incubated at field capacity for 4 weeks, air dried and thoroughly mixed before planting the cover crops. Experiment was conducted in plastic pots with $7 \mathrm{~kg}$ soil in each pot. Experimental design was randomized block arranged in a split plot. Copper levels were in the main plots and cover crops in the sub-plots. After germination, four plants were maintained in each pot. Plants were harvested 50 days after sowing. After harvesting the shoots, roots were removed from the soil manually and washed in water and distilled water several times. Maximum root length was measured. Plant materials were dried in a forced draft oven at $70^{\circ} \mathrm{C}$ to a constant weight and dry weights were recorded. The contribution of roots in the total plant weight was calculated using the following equation:

$$
\text { Contribution of root in total plant wt. }(\%)=\frac{\text { Root dry weight }}{\text { Root plus shoot dry weight }} \times 100
$$

where root and shoot dry weight was in g plant ${ }^{-1}$. 
Table 1. Common and scientific names of nine legume cover crop species used in the experiment.

\begin{tabular}{cc}
\hline Common name & Scientific name \\
\hline 1. Crotalaria (Smooth crotalaria) & Crotalaria mucronata (C. pallida Aiton) \\
2. Crotalaria (Showy Crotalaria) & Crotalaria spectabilis Roth \\
3. Calopogonio (Calapo) & Calopogonium mucunoides \\
4. Pueraria (Tropical Kudzu) & Pueraria phaseoloides Roxb. \\
5. Pigeonpea (black) & Cajanus cajan L. Millspaugh \\
6. Lablab & Lablab purpureus L. Sweet \\
7. Black velvet bean & Mucuna aterrima Piper \& Tracy \\
8. Gray velvet bean (Bengal bean) & Mucuna cinereum L. \\
9 Jack bean & Canavalia ensiformis L. DC. \\
\hline
\end{tabular}

Plant shoot materials were ground and analyzed for copper according to the methodology of Silva [9]. Copper use efficiency was calculated using the following equation:

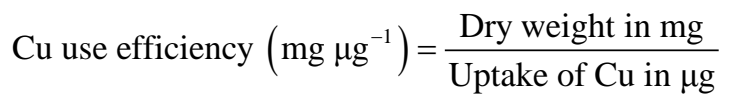

Soil samples were taken after removing roots and soil chemical properties were determined.

SAS was used for Analysis of variance and Tukey's mean separation and quadratic regression models were used to describe shoot dry weight, root dry weight and maximum root length responses to $\mathrm{Cu}$ application and soil chemical properties or indices. The quadratic response function is the most common functional form to evaluate the yield response to fertilizer rates and soil chemical properties or indices. The quadratic model is a second order polynomial function written as:

$$
\mathrm{Y}=\mathrm{a}+\mathrm{bx}+\mathrm{cx}^{2}
$$

where $\mathrm{Y}=$ the estimated yield, $\mathrm{X}=$ application rate of $\mathrm{Cu}$ and soil chemical properties or indices. The a, b, c are coefficients estimated by fitting the model to the data. The quadratic function assumes that cover crop shoot dry weight, root dry weight and maximum root length will increase at a decreasing rate as the $\mathrm{Cu}$ application rate increases until the maximum yield is achieved at a determined $\mathrm{Cu}$ rate

\section{Results and Discussion}

\subsection{Shoot Dry Weight}

Shoot dry weight of nine cover crop species was significantly affected by soil applied Cu rates and cover crop species and their interactions (Table 2). The significant $\mathrm{Cu} \mathrm{X}$ cover crop interaction indicates that cover crops responded differently with the change in soil applied $\mathrm{Cu}$ rates and hence, evaluation for different $\mathrm{Cu}$ use efficiency is desirable. Shoot dry weight varied from $0.53 \mathrm{~g} \mathrm{plant}^{-1}$ by cover crop species tropical kudzu to $4.45 \mathrm{~g}$ plant ${ }^{-1}$ produced by lablab, with an average value of $2.13 \mathrm{~g} \mathrm{plant}^{-1}$ at $0 \mathrm{mg} \mathrm{Cu} \mathrm{kg}^{-1}$ treatment. At the $5 \mathrm{mg} \mathrm{Cu}^{-1}$ $\mathrm{kg}^{-1}$ treatment, shoot dry weight varied from 0.49 to $6.72 \mathrm{~g} \mathrm{plant}^{-1}$, with an average value of $2.56 \mathrm{~g} \mathrm{plant}^{-1}$. At the $10 \mathrm{mg} \mathrm{Cu} \mathrm{kg}^{-1}$ treatment, shoot dry weight varied from 0.52 to $8.12 \mathrm{~g} \mathrm{plant}^{-1}$, with an average value of 3.21 g plant ${ }^{-1}$. Similarly, at the $20 \mathrm{mg} \mathrm{Cu} \mathrm{kg}^{-1}$ treatment, shoot dry weight varied from 0.47 to $9.74 \mathrm{~g} \mathrm{plant}^{-1}$, with an average value of $2.77 \mathrm{~g}$ plant $^{-1}$. Across the four soils applied $\mathrm{Cu}$ rates, shoot dry weight varied from $0.50 \mathrm{~g}$ plant $^{-1}$ produced by cover crop Pueraria (tropical kudzu) to $7.23 \mathrm{~g}$ plant $^{-1}$ produced by crop species Jack bean, with an average value of $2.66 \mathrm{~g} \mathrm{plant}^{-1}$. At all soil Cu levels Jack bean recorded the highest shoot wt and Pueraria recorded the lowest shoot wt. Overall, cover crop species responded significantly in a quadratic fashion with the increasing $\mathrm{Cu}$ rate in the range of 0 to $20 \mathrm{mg} \mathrm{kg}^{-1}$ soil $\left(\mathrm{Y}=2.07+0.16 \mathrm{X}-0.0064 \mathrm{X}^{2}, \mathrm{R}^{2}=0.68 * *\right)$. Based on quadratic regression equation, maximum shoot dry weight was obtained with the application of $13 \mathrm{mg} \mathrm{Cu}$ $\mathrm{kg}^{-1}$ of soil. Growth of these two cover crops species increased with the addition of $\mathrm{Cu}$ fertilization compared with control treatment. Significant variation in shoot dry weight among tropical legume cover crop species grown on Brazilian Oxisol has been reported by Fageria et al. [10]. Similarly, response to Cu fertilization by legume crops grown in acidic Cerrado soils has been reported by Fageria [11] and Fageria [12]. Lucas and Knezek [13] reported that for responsive crops the $\mathrm{Cu}$ concentration should exceed 4 to $6 \mathrm{mg} \mathrm{kg}^{-1}$ for mineral soils and 
Table 2. Shoot dry weight (g plant ${ }^{-1}$ ) of nine cover crops as influenced by copper application rates.

\begin{tabular}{|c|c|c|c|c|c|}
\hline \multirow[t]{2}{*}{ Cover crop species } & \multicolumn{4}{|c|}{ Cu rate $\left(\mathrm{mg} \mathrm{kg}^{-1}\right)$} & \multirow[t]{2}{*}{ Average } \\
\hline & 0 & 5 & 10 & 20 & \\
\hline 1. Crotalaria (Smooth crotalaria) & $0.67 \mathrm{c}$ & $0.56 \mathrm{~d}$ & $0.82 \mathrm{c}$ & $0.49 c$ & $0.63 d$ \\
\hline 2. Crotalaria (Showy Crotalaria) & $1.23 \mathrm{c}$ & $1.29 \mathrm{~cd}$ & $1.73 c$ & $0.93 c$ & $1.30 \mathrm{~d}$ \\
\hline 3. Calopogonio (Calapo) & $1.12 \mathrm{c}$ & $1.84 \mathrm{~cd}$ & $1.33 c$ & $1.26 \mathrm{c}$ & $1.39 \mathrm{~d}$ \\
\hline 4. Pueraria (Tropical Kudzu) & $0.53 c$ & $0.49 \mathrm{~d}$ & $0.52 c$ & $0.47 \mathrm{c}$ & $0.50 \mathrm{~d}$ \\
\hline 5. Pigeonpea (black) & $0.86 \mathrm{c}$ & $1.47 \mathrm{~cd}$ & $1.01 \mathrm{c}$ & $1.31 \mathrm{c}$ & $1.16 \mathrm{~d}$ \\
\hline 6. Lablab & $4.45 \mathrm{a}$ & 2.65bcd & $4.21 \mathrm{~b}$ & $1.24 \mathrm{c}$ & 3.13c \\
\hline 7. Black velvet bean & $3.10 \mathrm{~b}$ & 4.91ab & $6.04 \mathrm{~b}$ & $4.45 b$ & $4.62 b$ \\
\hline 8. Gray velvet bean (Bengal bean) & $2.80 \mathrm{~b}$ & $3.10 \mathrm{bc}$ & $5.10 \mathrm{~b}$ & $5.09 b$ & $4.03 \mathrm{bc}$ \\
\hline 9 Jack bean & $4.35 a$ & $6.72 \mathrm{a}$ & 8.12a & $9.74 a$ & $7.23 \mathrm{a}$ \\
\hline Average & $2.13 b$ & $2.56 \mathrm{ab}$ & $3.21 \mathrm{a}$ & $2.77 a b$ & 2.66 \\
\hline \multicolumn{6}{|l|}{ F-Test } \\
\hline Copper rate $(\mathrm{Cu})$ & & & & & $* *$ \\
\hline Cover crop species (C) & & & & & $* *$ \\
\hline $\mathrm{Cu}$ X C & & & & & $* *$ \\
\hline CVCu (\%) & & & & & 11.52 \\
\hline CVC (\%) & & & & & 7.28 \\
\hline
\end{tabular}

${ }^{* *}$ Significant at the $1 \%$ probability level. Means followed by the same letter in the same column are not significant at the $5 \%$ probability level by the Tukeys test. Values of averages are compared in the same line.

20 to $30 \mathrm{mg} \mathrm{kg}^{-1}$ for organic soils.

\subsection{Root Dry Weight}

Root dry weight was significantly affected by $\mathrm{Cu}$ treatment, cover crop species and their interactions (Table 3). A significant $\mathrm{Cu} X$ cover crop species interaction indicates that the nine cover crops reacted differently to

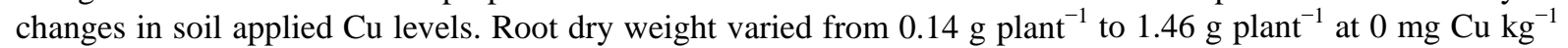
soil level, with an average value of $0.67 \mathrm{~g} \mathrm{~kg}^{-1}$. At $5 \mathrm{mg} \mathrm{Cu} \mathrm{kg}{ }^{-1}$ soil level, root dry weight varied from 0.22 to

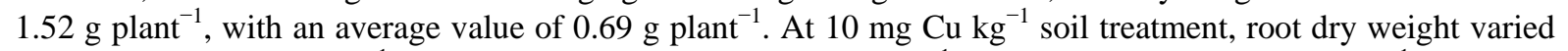

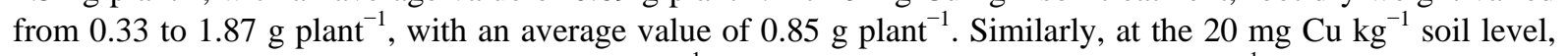
root dry weight varied from 0.10 to $1.57 \mathrm{~g}$ plant $^{-1}$, with an average value of $0.73 \mathrm{~g} \mathrm{plant}^{-1}$. Across all four soils applied $\mathrm{Cu}$ levels, root dry weight varied from 0.21 to $1.57 \mathrm{~g} \mathrm{plant}^{-1}$, with an average value of $0.74 \mathrm{~g} \mathrm{plant}^{-1}$. At all soil $\mathrm{Cu}$ levels smooth crotalaria recorded the lowest and black velvet bean recorded the highest root dry weight, indicating that black velvet bean is good type of cover crop to increase soil organic matter. Overall, root dry weight decreased when soil applied Cu level was raised more than $10 \mathrm{mg} \mathrm{kg}^{-1}$. The average regression equation showing the relationship between root dry weight and soil Cu levels was $\mathrm{Y}=0.67+0.028 \mathrm{X}-0.0012 \mathrm{X}^{2}, \mathrm{R}^{2}$ $=0.52 *$. This means that $52 \%$ of variability in root dry weight was due to $\mathrm{Cu}$ fertilization. Based on the regression equation maximum root dry weight was achieved with the application of $12 \mathrm{mg} \mathrm{Cu} \mathrm{kg}{ }^{-1}$ soil. Improvement in root growth with the application of $\mathrm{Cu}$ in legume crops grown on Brazilian Oxisols has been reported by Fageria [14] and Fageria [15]. The decrease in root growth at higher $\mathrm{Cu}$ levels may be related to additional $\mathrm{Cu}$ cannot be efficiency assimilated due to lack of or inability to manufacture carbohydrates.

\subsection{Maximum Root Length}

Maximum root length of the nine crop species was significantly affected by soil copper levels, cover crop species and their interactions (Table 4). The significant interaction between soil Cu levels X cover crop species indicates that maximum root length of cover crop species varied with the change in Cu levels in the soil. Across four $\mathrm{Cu}$ levels, maximum root length varied from $18 \mathrm{~cm}$ produced by smooth crotalaria to $33.16 \mathrm{~cm}$ produced by Bengal bean, with an average value of $24.28 \mathrm{~cm}$. Overall, application of $\mathrm{Cu}$ increased maximum root length in a quadratic fashion $\left(\mathrm{Y}=20.50+0.90 \mathrm{X}-0.032 \mathrm{X}^{2}, \mathrm{R}^{2}=0.85 * *\right)$. The variation in maximum root length was $85 \%$ due to application of copper fertilization. Based on the regression equation, overall maximum root length of nine 
Table 3. Root dry weight ( $\mathrm{g}_{\text {plant }}{ }^{-1}$ ) of nine cover crops as influenced by copper application rates.

\begin{tabular}{|c|c|c|c|c|c|}
\hline \multirow[t]{2}{*}{ Cover crop species } & \multicolumn{4}{|c|}{ Cu rate $\left(\mathrm{mg} \mathrm{kg}^{-1}\right)$} & \multirow[t]{2}{*}{ Average } \\
\hline & 0 & 5 & 10 & 20 & \\
\hline 1. Crotalaria (Smooth crotalaria) & $0.14 \mathrm{~d}$ & $0.22 \mathrm{e}$ & $0.33 c$ & $0.17 \mathrm{~d}$ & $0.21 \mathrm{e}$ \\
\hline 2. Crotalaria (Showy Crotalaria) & $0.31 \mathrm{~d}$ & 0.45 bcde & $0.45 \mathrm{c}$ & $0.40 \mathrm{~cd}$ & $0.40 \mathrm{e}$ \\
\hline 3. Calopogonio (Calapo) & $0.21 \mathrm{~d}$ & 0.41cde & $0.25 \mathrm{c}$ & $0.31 \mathrm{~cd}$ & $0.29 \mathrm{e}$ \\
\hline 4. Pueraria (Tropical Kudzu) & $0.16 \mathrm{~d}$ & $0.37 \mathrm{de}$ & $0.40 \mathrm{c}$ & $0.10 \mathrm{~d}$ & $0.26 \mathrm{e}$ \\
\hline 5. Pigeonpea (black) & $0.46 \mathrm{~cd}$ & $0.81 \mathrm{bcd}$ & $0.96 b$ & $0.83 \mathrm{bc}$ & $0.76 \mathrm{~d}$ \\
\hline 6. Lablab & $1.20 \mathrm{ab}$ & 0.60bcde & $1.01 \mathrm{~b}$ & $0.48 \mathrm{~cd}$ & $0.82 \mathrm{~cd}$ \\
\hline 7. Black velvet bean & $1.31 \mathrm{a}$ & $1.52 \mathrm{a}$ & $1.87 \mathrm{a}$ & $1.57 \mathrm{a}$ & $1.57 \mathrm{a}$ \\
\hline 8. Gray velvet bean (Bengal bean) & $1.46 \mathrm{a}$ & $0.92 b c$ & $1.29 \mathrm{~b}$ & $1.44 a$ & $1.28 \mathrm{~b}$ \\
\hline 9 Jack bean & $0.79 b c$ & $0.97 \mathrm{~b}$ & $1.15 b$ & $1.24 \mathrm{ab}$ & $1.04 \mathrm{c}$ \\
\hline Average & $0.67 \mathrm{~b}$ & $0.69 \mathrm{~b}$ & $0.85 a$ & $0.73 \mathrm{~b}$ & 0.74 \\
\hline \multicolumn{6}{|l|}{ F-Test } \\
\hline Copper rate $(\mathrm{Cu})$ & & & & & $* *$ \\
\hline Cover crop species (C) & & & & & $* *$ \\
\hline $\mathrm{CuXC}$ & & & & & $* *$ \\
\hline CVCu (\%) & & & & & 19.37 \\
\hline CVC (\%) & & & & & 22.23 \\
\hline
\end{tabular}

${ }^{* *}$ Significant at the $1 \%$ probability level. Means followed by the same letter in the same column are not significant at the $5 \%$ probability level by the Tukeys test. Values of averages are compared in the same line.

Table 4. Maximum root length $(\mathrm{cm})$ of nine cover crops as influenced by copper application rates.

\begin{tabular}{|c|c|c|c|c|c|}
\hline \multirow[t]{2}{*}{ Cover crop species } & \multicolumn{4}{|c|}{ Cu rate $\left(\mathrm{mg} \mathrm{kg}^{-1}\right)$} & \multirow[t]{2}{*}{ Average } \\
\hline & 0 & 5 & 10 & 20 & \\
\hline 1. Crotalaria (Smooth crotalaria) & 16.00cde & $18.33 b$ & $20.33 b c$ & $17.33 \mathrm{~d}$ & $18.00 \mathrm{e}$ \\
\hline 2. Crotalaria (Showy Crotalaria) & 19.33bcd & 25.33ab & $21.00 \mathrm{bc}$ & 25.66abcd & 22.83cd \\
\hline 3. Calopogonio (Calapo) & 11.66ef & 26.00ab & 28.66ab & 26.66abc & $23.25 \mathrm{~cd}$ \\
\hline 4. Pueraria (Tropical Kudzu) & 15.00de & 22.00ab & $17.66 \mathrm{c}$ & $19.66 \mathrm{~cd}$ & 18.58de \\
\hline 5. Pigeonpea (black) & $8.00 \mathrm{f}$ & 22.33ab & $21.66 \mathrm{bc}$ & 24.00bcd & 19.00de \\
\hline 6. Lablab & $31.66 \mathrm{a}$ & 25.00ab & $27.00 \mathrm{abc}$ & 24.33abcd & $27.00 \mathrm{bc}$ \\
\hline 7. Black velvet bean & $22.00 \mathrm{~b}$ & 29.66ab & $30.00 \mathrm{ab}$ & $32.00 \mathrm{ab}$ & 28.41ab \\
\hline 8. Gray velvet bean (Bengal bean) & $35.66 \mathrm{a}$ & 28.66ab & $35.00 \mathrm{a}$ & 33.33a & 33.16a \\
\hline 9 Jack bean & $21.00 \mathrm{bc}$ & 32.00a & $28.00 \mathrm{abc}$ & 32.33ab & $28.33 b$ \\
\hline Average & $20.03 b$ & $25.48 \mathrm{a}$ & $25.48 \mathrm{a}$ & $26.14 a$ & 24.28 \\
\hline \multicolumn{6}{|l|}{ F-Test } \\
\hline Copper rate (Cu) & & & & & $* *$ \\
\hline Cover crop species (C) & & & & & $* *$ \\
\hline Cu X C & & & & & ** \\
\hline CVCu (\%) & & & & & 8.77 \\
\hline CVC (\%) & & & & & 15.10 \\
\hline
\end{tabular}

\footnotetext{
${ }^{* *}$ Significant at the $1 \%$ probability level. Means followed by the same letter in the same column are not significant at the $5 \%$ probability level by the
} Tukeys test. Values of averages are compared in the same line.

crop species was achieved with the application of $14 \mathrm{mg} \mathrm{Cu} \mathrm{kg}^{-1}$ soil. Improvement in the root length of legume crops with the application of $\mathrm{Cu}$ in the Brazilian Oxisols has been reported by Fageria [15]. Maximum root length had a significant exponential quadratic relationship with shoot dry weight $\left(\mathrm{Y}=0.73\right.$ exp. $\left.-0.046 \mathrm{X}+0.0032 \mathrm{X}^{2}, \mathrm{R}^{2}=0.59 * *\right)$. Fageria and Moreira [16] reported significant quadratic association between maximum root length and shoot dry weight of tropical legume cover crops. 


\subsection{Contribution of Root in the Total Plant Weight}

Contribution of root in the total plant weight was significantly affected by soil copper levels, cover crop species and their interactions (Table 5). Significant interaction of $\mathrm{Cu}$ X crop species indicates that cover crops contributed differently in total plant weight under various $\mathrm{Cu}$ rates. Across four $\mathrm{Cu}$ levels, contribution of roots in the total plant weight varied from 13.03 to $41.41 \%$, with an average value of $25.19 \%$. The distribution of photosynthetic products in the roots and shoots is determined genetically, but also varies with environmental conditions [17]-[19]. Similar contribution of cover crop roots in the total plant weight was reported by Fageria and Moreira $[16]$.

\subsection{Concentration, Uptake and Use Efficiency of Copper}

Concentration (content per unit dry weight) of copper was significantly affected by soil applied copper rates, cover crop species and their interactions (Table 6). The significant interaction between soil copper X cover species indicates that $\mathrm{Cu}$ concentration in the crop species varied with the change by soil applied Cu rates. Across four soil applied $\mathrm{Cu}$ rates, the copper concentration in the shoots of cover crop species varied from $2.24 \mathrm{mg} \mathrm{kg}^{-1}$ to $8.20 \mathrm{mg} \mathrm{kg}^{-1}$, with an average value of $5.38 \mathrm{mg} \mathrm{kg}^{-1}$. The variation in Cu content among cover crop species was due to variation in dry weight. The Cu concentration in the shoot of Jack bean was the lowest although Jack bean had the maximum dry weight. Conversely, tropical kudzu had the highest $\mathrm{Cu}$ concentration but the minimum dry weight. The concentration of a nutrient related to dry weight is known as dilution effect in the field of mineral nutrition [2]. Higher dry matter yield means more dilution effect or lower nutrient concentration and vice versa. Overall, $\mathrm{Cu}$ concentration decreased in a quadratic fashion with increasing soil applied Cu rates $\left(\mathrm{Y}=5.29-0.25 \mathrm{X}+0.01 \mathrm{X}^{2}, \mathrm{R}^{2}=0.72 * *\right)$, because dry weight increased with the increasing soil applied $\mathrm{Cu}$ rates.

Uptake (concentration x dry weight) of copper was also significantly influenced by soil applied Cu rates, cover crops and their interactions (Table 7). Jack bean recorded maximum Cu uptake and tropical kudzu absorbed minimum amount of $\mathrm{Cu}$. This trend (maximum and minimum) was related to shoot dry weight of these two cover crop species. Hence, a cover crop which produces higher dry weight will absorb a larger amount of nutrient from the soil and will also add more nutrients back to the soil if incorporated or left on the soil surface compared to cover crop species which produce lower dry weights. Variation in dry weight and nutrient accumulation among cover crop species is widely reported [19] [20].

Copper use efficiency (units of dry weight produced per unit of Cu uptake) was significantly affected by cover crop species (Table 8). Baligar et al. [21] have reported interspecific variation in micronutrient use efficiency in several tropical legumes. Copper use efficiency varied from $142.08 \mathrm{mg}$ per $\mu \mathrm{g}$ Cu uptake in tropical kudzu to $484.06 \mathrm{mg}$ per $\mu \mathrm{g} \mathrm{Cu}$ uptake in jack bean, with an average value of $272.11 \mathrm{mg}$ per $\mu \mathrm{g}$ Cu uptake. The lower value of Cu use efficiency in tropical kudzu and higher Cu use efficiency in jack bean was related to dry weight of shoots. In the case of tropical kudzu, shoot dry weight was lower and the Cu uptake value was lower so the $\mathrm{Cu}$ use efficiency was lower. Jack bean was the opposite case. Cover crop species having high Cu use efficiency might produce higher yield when grown on $\mathrm{Cu}$ deficient tropical soils.

\subsection{Soil pH and Mehlich 1 Extractable Soil Copper, Zinc, Iron and Manganese}

Soil pH was significantly affected by copper fertilization, cover crop species and their interaction (Table 9). Across four soil applied $\mathrm{Cu}$ levels, soil $\mathrm{pH}$ varied from 5.79 to 6.42 depending on cover crop species. Cover crop species calopogonia had the lowest $\mathrm{pH}$ at harvest while crop species jack bean had the highest soil $\mathrm{pH}$. The difference in soil pH among crop species may be related to the difference in uptake of cations and anions. Tang and Rengel [22] reported that unbalanced uptake of cations and anions by plants tend to cause in pH changes in the rhizosphere as well as charge imbalance in the plant. Excess cation uptake by the root is associated with a $\mathrm{pH}$ decrease due to release of $\mathrm{H}+$ ions in the rhizosphere and excess uptake of anions results in $\mathrm{pH}$ increase due to release of $\mathrm{OH}$ - ions [22]. Copper fertilization also increases soil $\mathrm{pH}$ significantly. Overall, the increase in $\mathrm{pH}$ with the addition of $\mathrm{Cu}$ was quadratic in fashion $\left(\mathrm{Y}=5.83+5.30 \mathrm{X}-0.0019 \mathrm{X}^{2}, \mathrm{R}^{2}=0.90 * *\right)$. This increase in soil $\mathrm{pH}$ may be related to excess uptake of sulfate (the copper source was copper sulfate) ions by the plants which resulted in release of $\mathrm{OH}$ - ions in the rhizosphere. Soil extractable copper was significantly affected by applied Cu rates (Table 10). The increase in Mehlich 1 extractable soil Cu was linear 
Table 5. Contribution of root in the total plant weight (\%) of nine cover crops as influenced by copper application rates.

\begin{tabular}{|c|c|c|c|c|c|}
\hline \multirow[t]{2}{*}{ Cover crop species } & \multicolumn{4}{|c|}{ Cu rate $\left(\mathrm{mg} \mathrm{kg}^{-1}\right)$} & \multirow[t]{2}{*}{ Average } \\
\hline & 0 & 5 & 10 & 20 & \\
\hline 1. Crotalaria (Smooth crotalaria) & 17.37ab & 27.34abc & 29.63bc & 25.66abc & $25.00 \mathrm{bc}$ \\
\hline 2. Crotalaria (Showy Crotalaria) & 19.91ab & $25.36 \mathrm{bc}$ & 20.61c & 30.53ab & $24.10 \mathrm{bc}$ \\
\hline 3. Calopogonio (Calapo) & $18.40 \mathrm{ab}$ & $18.56 \mathrm{c}$ & $15.49 c$ & $20.44 b c$ & $18.22 \mathrm{~cd}$ \\
\hline 4. Pueraria (Tropical Kudzu) & 23.28ab & $44.17 \mathrm{a}$ & 43.38ab & $18.74 \mathrm{bc}$ & $32.39 b$ \\
\hline 5. Pigeonpea (black) & $40.91 \mathrm{a}$ & 36.24ab & $50.12 \mathrm{a}$ & $38.38 \mathrm{a}$ & $41.41 \mathrm{a}$ \\
\hline 6. Lablab & 21.29ab & $18.31 \mathrm{c}$ & $19.15 c$ & 27.88ab & $21.65 \mathrm{~cd}$ \\
\hline 7. Black velvet bean & 29.42ab & $24.64 \mathrm{bc}$ & 23.86bc & 26.43ab & $26.09 b c$ \\
\hline 8. Gray velvet bean (Bengal bean) & $34.05 \mathrm{ab}$ & $22.96 \mathrm{bc}$ & 20.61c & $21.85 b c$ & $24.86 \mathrm{bc}$ \\
\hline 9 Jack bean & $15.49 b$ & $12.36 \mathrm{c}$ & $12.64 c$ & $11.63 \mathrm{c}$ & $13.03 d$ \\
\hline Average & $24.45 a$ & $25.55 a$ & $26.16 \mathrm{a}$ & $24.61 \mathrm{a}$ & 25.19 \\
\hline \multicolumn{6}{|l|}{ F-Test } \\
\hline Copper rate $(\mathrm{Cu})$ & & & & & $* *$ \\
\hline Cover crop species (C) & & & & & $* *$ \\
\hline $\mathrm{Cu}$ X C & & & & & ** \\
\hline CVCu (\%) & & & & & 28.82 \\
\hline CVC (\%) & & & & & 27.01 \\
\hline
\end{tabular}

${ }^{* *}$ Significant at the $1 \%$ probability level. Means followed by the same letter in the same column are not significant at the $5 \%$ probability level by the Tukeys test. Values of averages are compared in the same line.

Table 6. Concentration of copper $\left(\mathrm{mg} \mathrm{kg}^{-1}\right)$ in the shoots of nine cover crop species as influenced by copper application rates.

\begin{tabular}{|c|c|c|c|c|c|}
\hline \multirow[t]{2}{*}{ 'Cover crop species } & \multicolumn{4}{|c|}{$\mathrm{Cu}$ rate $\left(\mathrm{mg} \mathrm{kg}^{-1}\right)$} & \multirow[t]{2}{*}{ Average } \\
\hline & 0 & 5 & 10 & 20 & \\
\hline 1. Crotalaria (Smooth crotalaria) & 4.15bcd & $6.16 \mathrm{ab}$ & $4.41 \mathrm{ab}$ & $5.95 a$ & $5.17 \mathrm{bc}$ \\
\hline 2. Crotalaria (Showy Crotalaria) & $6.45 \mathrm{bc}$ & $5.03 \mathrm{bc}$ & $4.88 \mathrm{ab}$ & $6.35 \mathrm{a}$ & $5.68 b$ \\
\hline 3. Calopogonio (Calapo) & 3.92cd & 3.37de & $4.43 a b$ & $5.01 \mathrm{ab}$ & 4.18cd \\
\hline 4. Pueraria (Tropical Kudzu) & 13.39a & $7.08 \mathrm{a}$ & $6.47 \mathrm{a}$ & $5.86 a$ & $8.20 \mathrm{a}$ \\
\hline 5. Pigeonpea (black) & $7.40 \mathrm{~b}$ & 4.31cd & $4.55 \mathrm{ab}$ & $4.87 \mathrm{ab}$ & $5.28 \mathrm{bc}$ \\
\hline 6. Lablab & $2.51 \mathrm{~d}$ & $2.34 \mathrm{ef}$ & $2.60 \mathrm{~b}$ & $2.65 b$ & 2.52ef \\
\hline 7. Black velvet bean & $3.60 \mathrm{~cd}$ & 3.35de & $2.90 \mathrm{~b}$ & 4.33ab & 3.54de \\
\hline 8. Gray velvet bean (Bengal bean) & 4.61bcd & 3.10def & $3.32 b$ & $3.96 \mathrm{ab}$ & 3.74de \\
\hline 9 Jack bean & $2.38 \mathrm{~d}$ & $1.95 f$ & $2.55 b$ & $2.09 \mathrm{~b}$ & $2.24 \mathrm{f}$ \\
\hline Average & $5.38 \mathrm{a}$ & $4.07 \mathrm{~b}$ & $4.01 \mathrm{~b}$ & $4.56 \mathrm{ab}$ & 5.38 \\
\hline \multicolumn{6}{|l|}{ F-Test } \\
\hline Copper rate $(\mathrm{Cu})$ & & & & & $* *$ \\
\hline Cover crop species (C) & & & & & $* *$ \\
\hline $\mathrm{Cu} \mathrm{X} \mathrm{C}$ & & & & & $* *$ \\
\hline $\mathrm{CVCu}(\%)$ & & & & & 23.95 \\
\hline CVC(\%) & & & & & 21.24 \\
\hline
\end{tabular}

${ }^{* *}$ Significant at the $1 \%$ probability level. Means followed by the same letter in the same column are not significant at the $5 \%$ probability level by the Tukeys test. Values of averages are compared in the same line.

$\left(\mathrm{Y}=1.29+1.062 \mathrm{X}, \mathrm{R}^{2}=0.99 * *\right)$ with the addition of $\mathrm{Cu}$ fertilizer in the range of 0 to $20 \mathrm{mg} \mathrm{kg}^{-1}$ soil as expected. Mehlich 1 extractable soil $\mathrm{Cu}$ in the control treatment was higher at harvest compared to original soil $\mathrm{Cu}$ value (1.4 mg kg$~^{-1}$ versus $1.2 \mathrm{mg} \mathrm{kg}^{-1}$ ) and this may be related to lime addition. Barber [23] reported that liming materials contain $\mathrm{Cu}$ in the range of 0.3 to $89 \mathrm{~g} \mathrm{~kg}^{-1}$, with an average value of $2.7 \mathrm{~g} \mathrm{~kg}^{-1}$.

Overall, maximum growth of shoot and root was achieved with the Mehlich 1 extractable soil copper of 16 and $14 \mathrm{mg} \mathrm{kg}^{-1}$ soil, respectively (Table 11). Similarly, maximum root length (MRL) was obtained with the 
Table 7. Uptake of copper $\left(\mu\right.$ plant $\left.^{-1}\right)$ in the shoots of nine cover crop species as influenced by copper application rates.

\begin{tabular}{|c|c|c|c|c|c|}
\hline \multirow[t]{2}{*}{ Cover crop species } & \multicolumn{4}{|c|}{$\mathrm{Cu}$ rate $\left(\mathrm{mg} \mathrm{kg}^{-1}\right)$} & \multirow[t]{2}{*}{ Average } \\
\hline & 0 & 5 & 10 & 20 & \\
\hline 1. Crotalaria (Smooth crotalaria) & $2.85 b$ & $3.49 \mathrm{c}$ & $3.77 \mathrm{c}$ & $2.92 b$ & $3.25 c$ \\
\hline 2. Crotalaria (Showy Crotalaria) & $8.00 \mathrm{ab}$ & $6.53 \mathrm{bc}$ & $8.50 \mathrm{bc}$ & $5.99 \mathrm{~b}$ & $7.25 \mathrm{bc}$ \\
\hline 3. Calopogonio (Calapo) & 4.17ab & $6.24 \mathrm{bc}$ & $5.86 \mathrm{bc}$ & $6.38 \mathrm{~b}$ & $5.66 \mathrm{bc}$ \\
\hline 4. Pueraria (Tropical Kudzu) & 7.33ab & $3.44 \mathrm{c}$ & $3.55 c$ & $2.74 b$ & $4.26 \mathrm{bc}$ \\
\hline 5. Pigeonpea (black) & 6.18ab & $6.32 \mathrm{bc}$ & $4.57 \mathrm{c}$ & $6.45 b$ & $5.88 \mathrm{bc}$ \\
\hline 6. Lablab & 11.14ab & $6.25 b c$ & $10.99 \mathrm{abc}$ & $3.35 b$ & $7.93 b$ \\
\hline 7. Black velvet bean & 11.11ab & $16.24 a$ & 17.69ab & 19.34a & $16.09 \mathrm{a}$ \\
\hline 8. Gray velvet bean (Bengal bean) & 13.13a & 9.66abc & 17.03ab & $20.29 a$ & $15.03 a$ \\
\hline 9 Jack bean & $10.65 \mathrm{ab}$ & 13.13ab & 21.19a & $19.41 \mathrm{a}$ & $16.09 a$ \\
\hline Average & $8.28 \mathrm{a}$ & $7.92 \mathrm{a}$ & $10.35 a$ & $9.65 a$ & 9.05 \\
\hline \multicolumn{6}{|l|}{ F-Test } \\
\hline Copper rate $(\mathrm{Cu})$ & & & & & $* *$ \\
\hline Cover crop species (C) & & & & & $* *$ \\
\hline $\mathrm{Cu}$ X C & & & & & $* *$ \\
\hline $\mathrm{CVCu}(\%)$ & & & & & 36.55 \\
\hline CVC(\%) & & & & & 36.07 \\
\hline
\end{tabular}

${ }^{* *}$ Significant at the $1 \%$ probability level. Means followed by the same letter in the same column are not significant at the $5 \%$ probability level by the Tukey's test. Values of averages are compared in the same line.

Table 8. Copper use efficiency $\left(\mathrm{mg}^{-1} \mathrm{~g}^{-1}\right.$ ) in the shoots of nine cover crop species as influenced by copper application rates. Copper use efficiency values are across four copper levels.

\begin{tabular}{|c|c|}
\hline Cover crop species & Copper use efficiency $\left(\mathrm{mg}_{\mu} \mathrm{g}^{-1}\right.$ ) \\
\hline 1. Crotalaria (Smooth crotalaria) & 208.78bcd \\
\hline 2. Crotalaria (Showy Crotalaria) & 180.40cd \\
\hline 3. Calopogonio (Calapo) & $238.49 \mathrm{bcd}$ \\
\hline 4. Pueraria (Tropical Kudzu) & $142.08 \mathrm{~d}$ \\
\hline 5. Pigeonpea (black) & 208.00bcd \\
\hline 6. Lablab & $416.97 a$ \\
\hline 7. Black velvet bean & $294.12 b$ \\
\hline 8. Gray velvet bean (Bengal bean) & $276.12 b c$ \\
\hline 9 Jack bean & $484.06 \mathrm{a}$ \\
\hline Average & 272.11 \\
\hline \multicolumn{2}{|l|}{ F-Test } \\
\hline Copper rate $(\mathrm{Cu})$ & NS \\
\hline Cover crop species (C) & $* *$ \\
\hline $\mathrm{Cu}$ X C & NS \\
\hline $\mathrm{CVCu}(\%)$ & 29.32 \\
\hline CVC(\%) & 28.62 \\
\hline
\end{tabular}

\footnotetext{
${ }^{* *}$, Ns Significant at the $1 \%$ probability level and not significant, respectively. Means followed by the same letter in the same column are not significant at the $5 \%$ probability level by the Tukeys test.
}

Mehlich 1 extractable soil $\mathrm{Cu}$ of $17 \mathrm{mg} \mathrm{kg}^{-1}$ soil. Variation in shoot and root growth due to extractable soil $\mathrm{Cu}$ was in the order of maximum root length $>$ root dry weight $>$ shoot dry weight (Table 11). Hence, root growth was more sensitive to copper deficiency compared to shoot growth. Improvement in root growth of legumes with the addition of $\mathrm{Cu}$ has been reported by Fageria [15]. Mehlich 1 extractable soil Zn, Mn and Fe were significantly affected by $\mathrm{Cu}$ and cover crop species treatments, except $\mathrm{Zn}$ which was not affected by cover crop species (Tables 12-14). The Mehlich 1 extractable $\mathrm{Zn}, \mathrm{Mn}$ and Fe were significantly affected by soil ap- 
Table 9. Soil pH after harvest of nine cover crops as influenced by copper application rates.

\begin{tabular}{|c|c|c|c|c|c|}
\hline \multirow[t]{2}{*}{ Cover crop species } & \multicolumn{4}{|c|}{ Cu rate $\left(\mathrm{mg} \mathrm{kg}^{-1}\right)$} & \multirow[t]{2}{*}{ Average } \\
\hline & 0 & 5 & 10 & 20 & \\
\hline 1. Crotalaria (Smooth crotalaria) & $5.37 d$ & $5.87 \mathrm{bc}$ & $5.66 \mathrm{c}$ & $6.50 \mathrm{a}$ & $5.85 \mathrm{ef}$ \\
\hline 2. Crotalaria (Showy Crotalaria) & $5.56 \mathrm{~cd}$ & $5.66 \mathrm{~cd}$ & $5.96 \mathrm{bc}$ & $6.23 \mathrm{ab}$ & $5.85 \mathrm{ef}$ \\
\hline 3. Calopogonio (Calapo) & $5.53 \mathrm{~cd}$ & $5.40 \mathrm{~d}$ & $6.20 \mathrm{ab}$ & $6.03 \mathrm{bc}$ & $5.79 f$ \\
\hline 4. Pueraria (Tropical Kudzu) & $5.76 \mathrm{~cd}$ & $6.36 \mathrm{a}$ & $6.30 \mathrm{a}$ & $5.70 \mathrm{~d}$ & $6.03 \mathrm{c}$ \\
\hline 5. Pigeonpea (black) & 5.83bcd & $6.26 \mathrm{a}$ & $6.23 \mathrm{ab}$ & $5.76 \mathrm{~cd}$ & $6.03 c$ \\
\hline 6. Lablab & $5.50 \mathrm{~cd}$ & $6.40 \mathrm{a}$ & $6.43 a$ & $6.27 a b$ & $6.15 b c$ \\
\hline 7. Black velvet bean & $6.30 \mathrm{ab}$ & $6.17 \mathrm{ab}$ & $5.73 \mathrm{c}$ & $5.83 \mathrm{~cd}$ & 6.00cde \\
\hline 8. Gray velvet bean (Bengal bean) & $5.97 \mathrm{bc}$ & $6.20 \mathrm{ab}$ & 6.46a & 6.23ab & $6.21 b$ \\
\hline 9 Jack bean & $6.60 \mathrm{a}$ & $6.20 \mathrm{ab}$ & 6.43a & $6.43 a$ & $6.42 a$ \\
\hline Average & $5.82 b$ & $6.05 \mathrm{a}$ & $6.15 a$ & 6.11a & \\
\hline \multicolumn{6}{|l|}{ F-Test } \\
\hline Copper rate $(\mathrm{Cu})$ & & & & & $* *$ \\
\hline Cover crop species (C) & & & & & $* *$ \\
\hline $\mathrm{Cu}$ X C & & & & & $* *$ \\
\hline CVCu (\%) & & & & & 2.49 \\
\hline CVC (\%) & & & & & 2.17 \\
\hline
\end{tabular}

${ }^{* *}$ Significant at the $1 \%$ probability level. Means followed by the same letter in the same column are not significant at the $5 \%$ probability level by the Tukeys test. Values of averages are compared in the same line.

Table 10. Mehlich 1 extractable soil $\mathrm{Cu}$ as influenced by copper fertilization and cover crop species treatments.

\begin{tabular}{cc}
\hline Cover crop species/Copper levels & $\mathrm{Cu}\left(\mathrm{mg} \mathrm{kg}^{-1}\right)$ \\
\hline $\mathrm{Cu}\left(0 \mathrm{mg} \mathrm{kg}^{-1}\right)$ & $1.41 \mathrm{~d}$ \\
$\mathrm{Cu}\left(50 \mathrm{mg} \mathrm{kg}^{-1}\right)$ & $6.51 \mathrm{c}$ \\
$\mathrm{Cu}\left(10 \mathrm{mg} \mathrm{kg}^{-1}\right)$ & $11.82 \mathrm{~b}$ \\
$\mathrm{Cu}\left(20 \mathrm{mg} \mathrm{k}^{-1}\right)$ & $22.61 \mathrm{a}$ \\
1. Crotalaria (Smooth crotalaria) & $11.00 \mathrm{a}$ \\
2. Crotalaria (Showy Crotalaria) & $10.35 \mathrm{a}$ \\
3. Calopogonio (Calapo) & $10.30 \mathrm{a}$ \\
4. Pueraria (Tropical Kudzu) & $10.41 \mathrm{a}$ \\
5. Pigeonpea (black) & $10.55 \mathrm{a}$ \\
6. Lablab & $10.83 \mathrm{a}$ \\
7. Black velvet bean & $9.88 \mathrm{a}$ \\
8. Gray velvet bean (Bengal bean) & $11.34 \mathrm{a}$ \\
9 Jack bean & $10.64 \mathrm{a}$ \\
Average & \\
F-Test & \\
Copper rate (Cu) & $* *$ \\
Cover crop species (C) & NS \\
Cu X C & NS \\
CVCu(\%) & 9.51 \\
CVC(\%) & 19.21 \\
\hline
\end{tabular}

${ }^{* *}$ Significant at the $1 \%$ probability level. Means followed by the same letter in the same column are not significant at the $5 \%$ probability level by the Tukeys test. Values of Cu levels are compared separately in the same column.

Table 11. Relationship between Mehlich 1 extractable soil $\mathrm{Cu}$ and shoot dry weight (SDW), root dry weight (RDW) and maximum root length (MRL). Values are averages of nine cover crops.

\begin{tabular}{cccc}
\hline Variable & Regression equation & $\mathrm{R} 2$ & $\mathrm{Cu}\left(\mathrm{mg} \mathrm{kg}^{-1}\right)$ for maximum yield or length \\
\hline Cu vs SDW & $\mathrm{Y}=1.96+0.122 \mathrm{X}-0.0037 \mathrm{X}^{2}$ & $0.50^{*}$ & 16 \\
Cu vs RDW & $\mathrm{Y}=0.60+0.031 \mathrm{X}-0.0011 \mathrm{X}^{2}$ & $0.58^{*}$ & 14 \\
Cu vs MRL & $\mathrm{Y}=19.26+0.944 \mathrm{X}-0.0286 \mathrm{X}^{2}$ & $0.84^{* *}$ & 17 \\
\hline
\end{tabular}

\footnotetext{
${ }^{*, * *}$ Significant at the 5 and $1 \%$ probability levels, respectively.
} 
Table 12. Mehlich 1 extractable soil $\mathrm{Zn}$ as influenced by copper fertilization and cover crop species treatments.

\begin{tabular}{|c|c|c|c|c|c|}
\hline \multirow[t]{2}{*}{ Cover crop species } & \multicolumn{4}{|c|}{ Cu rate (mg kg-1) } & \multirow[t]{2}{*}{ Average } \\
\hline & 0 & 5 & 10 & 20 & \\
\hline 1. Crotalaria (Smooth crotalaria) & $0.56 \mathrm{~b}$ & $0.50 \mathrm{ab}$ & $0.50 \mathrm{~b}$ & $1.00 \mathrm{a}$ & $0.64 a$ \\
\hline 2. Crotalaria (Showy Crotalaria) & $0.53 \mathrm{~b}$ & $0.53 a b$ & $0.66 b$ & $0.93 a$ & $0.67 a$ \\
\hline 3. Calopogonio (Calapo) & $0.53 \mathrm{~b}$ & $0.36 b$ & $1.23 a$ & $0.80 \mathrm{a}$ & $0.73 a$ \\
\hline 4. Pueraria (Tropical Kudzu) & $0.83 a$ & $0.47 a b$ & $0.77 b$ & $0.73 a$ & $0.70 \mathrm{a}$ \\
\hline 5. Pigeonpea (black) & $0.53 \mathrm{~b}$ & $0.47 a b$ & $0.57 b$ & $0.88 \mathrm{a}$ & $0.61 \mathrm{a}$ \\
\hline 6. Lablab & $0.43 \mathrm{~b}$ & $0.63 a$ & $0.73 b$ & $1.13 \mathrm{a}$ & 0.73a \\
\hline 7. Black velvet bean & $0.60 \mathrm{~b}$ & $0.63 a$ & $0.70 \mathrm{~b}$ & 0.70a & $0.66 \mathrm{a}$ \\
\hline 8. Gray velvet bean (Bengal bean) & $0.50 \mathrm{~b}$ & $0.60 \mathrm{a}$ & $0.77 \mathrm{~b}$ & $0.93 a$ & 0.70a \\
\hline 9 Jack bean & $0.53 \mathrm{~b}$ & $0.53 \mathrm{ab}$ & $0.83 \mathrm{ab}$ & $1.10 \mathrm{~s}$ & $0.75 a$ \\
\hline Average & $0.56 \mathrm{c}$ & $0.53 c$ & $0.75 b$ & $0.91 \mathrm{a}$ & \\
\hline \multicolumn{6}{|l|}{ F-Test } \\
\hline Copper rate $(\mathrm{Cu})$ & & & & & $* *$ \\
\hline Cover crop species (C) & & & & & NS \\
\hline $\mathrm{Cu}$ X C & & & & & $* *$ \\
\hline $\mathrm{CVCu}(\%)$ & & & & & 18.12 \\
\hline CVC(\%) & & & & & 17.69 \\
\hline
\end{tabular}

${ }^{* *}$ Significant at the $1 \%$ probability level. Means followed by the same letter in the same column are not significant at the $5 \%$ probability level by the Tukeys test. Values of averages are compared in the same line.

Table 13. Mehlich 1 extractable soil Mn as influenced by copper fertilization and cover crop species treatments.

\begin{tabular}{|c|c|c|c|c|c|}
\hline \multirow[t]{2}{*}{ Cover crop species } & \multicolumn{4}{|c|}{$\mathrm{Cu}$ rate $\left(\mathrm{mg} \mathrm{kg}^{-1}\right)$} & \multirow[t]{2}{*}{ Average } \\
\hline & 0 & 5 & 10 & 20 & \\
\hline 1. Crotalaria (Smooth crotalaria) & 9.67de & $10.67 \mathrm{c}$ & 9.33c & 15.33ab & $11.25 \mathrm{ef}$ \\
\hline 2. Crotalaria (Showy Crotalaria) & 10.33cde & 8.33d & $15.67 \mathrm{ab}$ & $14.00 \mathrm{abc}$ & 12.08de \\
\hline 3. Calopogonio (Calapo) & $8.00 \mathrm{e}$ & $7.67 d$ & $14.33 b$ & $12.33 c d$ & $10.58 f$ \\
\hline 4. Pueraria (Tropical Kudzu) & 11.66bcd & 12.33abc & 13.33b & $12.33 \mathrm{~cd}$ & 12.41cde \\
\hline 5. Pigeonpea (black) & 11.00cd & 12.33abc & 13.00b & $12.33 \mathrm{~cd}$ & 12.17de \\
\hline 6. Lablab & 10.33cde & $12.00 \mathrm{bc}$ & $15.00 \mathrm{ab}$ & 13.67bcd & $12.75 \mathrm{~cd}$ \\
\hline 7. Black velvet bean & $15.00 \mathrm{a}$ & $14.00 \mathrm{ab}$ & $14.00 \mathrm{~b}$ & 11.33d & $13.58 \mathrm{bc}$ \\
\hline 8. Gray velvet bean (Bengal bean) & 13.67ab & 14.33a & 18.33a & 15.33ab & $15.41 \mathrm{a}$ \\
\hline 9 Jack bean & 12.67abc & $11.33 \mathrm{c}$ & 16.00ab & 16.33a & $14.08 \mathrm{~b}$ \\
\hline Average & $11.37 \mathrm{~b}$ & $11.44 b$ & 14.33a & $13.67 \mathrm{a}$ & \\
\hline \multicolumn{6}{|l|}{ F-Test } \\
\hline Copper rate $(\mathrm{Cu})$ & & & & & $* *$ \\
\hline Cover crop species (C) & & & & & $* *$ \\
\hline $\mathrm{Cu}$ X C & & & & & $* *$ \\
\hline $\mathrm{CVCu}(\%)$ & & & & & 7.79 \\
\hline CVC(\%) & & & & & 7.32 \\
\hline
\end{tabular}

${ }^{* *}$ Significant at the $1 \%$ probability level. Means followed by the same letter in the same column are not significant at the $5 \%$ probability level by the Tukeys test. Values of averages are compared in the same line.

plied $\mathrm{Cu} \mathrm{X}$ cover crops interactions. Hence, it can be concluded that uptake of these elements by cover crops varied with the change in $\mathrm{Cu}$ concentration in the growth medium. Mehlich 1 extractable soil $\mathrm{Zn}, \mathrm{Mn}$ and Fe increased with the addition of copper fertilizer (Table 15). The increase in $\mathrm{Zn}$ was linear when $\mathrm{Cu}$ was added in the range of 0 to $20 \mathrm{mg} \mathrm{kg}^{-1}$. However, the increase in $\mathrm{Mn}$ and $\mathrm{Fe}$ was quadratic in the same range of $\mathrm{Cu}$ addition. The increase in $\mathrm{Zn}, \mathrm{Mn}$ and Fe in the soil solution may be related to replacement of these cations on soil colloids by copper ions and resulted in their increased concentration in the soil solution. It has been reported by 
Table 14. Mehlich 1 extractable soil Fe as influenced by copper fertilization and cover crop species treatments.

\begin{tabular}{|c|c|c|c|c|c|}
\hline \multirow[t]{2}{*}{ Cover crop species } & \multicolumn{4}{|c|}{ Cu rate $\left(\mathrm{mg} \mathrm{kg}^{-1}\right)$} & \multirow[t]{2}{*}{ Average } \\
\hline & 0 & 5 & 10 & 20 & \\
\hline 1. Crotalaria (Smooth crotalaria) & 30.33a & $28.67 \mathrm{~b}$ & 31.33a & $27.67 \mathrm{a}$ & 29.50ab \\
\hline 2. Crotalaria (Showy Crotalaria) & $29.00 \mathrm{a}$ & $29.00 \mathrm{~b}$ & 31.33a & $27.66 a$ & $29.25 \mathrm{ab}$ \\
\hline 3. Calopogonio (Calapo) & 27.33a & $28.67 \mathrm{~b}$ & 30.33a & $26.00 \mathrm{a}$ & $28.08 \mathrm{~b}$ \\
\hline 4. Pueraria (Tropical Kudzu) & $30.67 a$ & $29.00 \mathrm{~b}$ & 31.33a & $26.00 \mathrm{a}$ & 29.25 \\
\hline 5. Pigeonpea (black) & $30.00 \mathrm{a}$ & $31.00 \mathrm{ab}$ & 30.33a & $26.00 \mathrm{a}$ & 29.33ab \\
\hline 6. Lablab & $29.00 \mathrm{a}$ & $31.00 \mathrm{ab}$ & $29.00 \mathrm{a}$ & 26.66a & 28.91ab \\
\hline 7. Black velvet bean & $29.00 \mathrm{a}$ & $33.00 \mathrm{a}$ & $29.00 \mathrm{a}$ & $27.00 \mathrm{a}$ & $29.67 a$ \\
\hline 8. Gray velvet bean (Bengal bean) & $29.67 a$ & $32.67 \mathrm{a}$ & $29.00 \mathrm{a}$ & $27.66 a$ & $29.75 a$ \\
\hline 9 Jack bean & $28.67 a$ & $29.33 b$ & $28.00 \mathrm{a}$ & 26.33a & $28.08 \mathrm{~b}$ \\
\hline Average & $29.37 a$ & $30.25 a$ & $29.96 a$ & $26.78 b$ & \\
\hline \multicolumn{6}{|l|}{ F-Test } \\
\hline Copper rate $(\mathrm{Cu})$ & & & & & $* *$ \\
\hline Cover crop species (C) & & & & & $* *$ \\
\hline $\mathrm{CuXC}$ & & & & & $* *$ \\
\hline $\mathrm{CVCu}(\%)$ & & & & & 5.05 \\
\hline CVC(\%) & & & & & 4.07 \\
\hline
\end{tabular}

${ }^{* *}$ Significant at the $1 \%$ probability level. Means followed by the same letter in the same column are not significant at the $5 \%$ probability level by the Tukeys test. Values of averages are compared in the same line.

Table 15. Influence of copper fertilization ( $\mathrm{mg} \mathrm{kg}^{-1}$ ) on Mehlich 1 extractable soil $\mathrm{Cu}, \mathrm{Zn}, \mathrm{Mn}$ and iron ( $\mathrm{mg} \mathrm{kg}^{-1}$ ).

\begin{tabular}{ccc}
\hline Variable & Regression equation & $\mathrm{R} 2$ \\
\hline Cu rate vs extractable soil $\mathrm{Zn}$ & $\mathrm{Y}=0.51+0.019 \mathrm{X}$ & $0.92^{* *}$ \\
Cu rate vs extractable soil $\mathrm{Mn}$ & $\mathrm{Y}=10.96+0.369 \mathrm{X}-0.011 \mathrm{X}^{2}$ & $0.68^{* *}$ \\
Cu rate vs extractable soil Fe & $\mathrm{Y}=29.39+0.255 \mathrm{X}-0.019 \mathrm{X}^{2}$ & $0.92^{* *}$ \\
\hline
\end{tabular}

Mengel et al. [24] and Brady and Weil [25] that Cu on soil colloids was held (adsorbed) more strongly compared to Zn, Mn and Fe.

\section{Conclusion}

Cover crops are important components of cropping systems to reduce leaching loss of nutrients and improve soil fertility thereby reducing the further degradation of the soils. Improvement in growth and development of cover crop species is an important strategy in accumulation of large amounts of nutrients in cover crops biomass and the succeeding crops of economic value, once cover crop residues are incorporated in the soil. Copper fertilization improved shoot and root growth of tropical legume cover crop species. Hence, the use of adequate amounts of copper is one of the strategies to improve growth of tropical legume cover crops grown on tropical Oxisols. However, improvement in these plant growth parameters varied with crop species. Some species produced significantly higher shoot and root growth compared to other species. This means selecting cover crops for copper use efficiency is an important strategy in improving soil fertility of these acidic infertile soils.

\section{Acknowledgements}

We thank M. K. Elson and L. F. Stone for excellent review and editing of this paper.

\section{References}

[1] Baligar, V.C. and Fageria, N.K. (2007) Agronomy and Physiology of Tropical Cover Crops. Journal of Plant Nutrition, 30, 1287-1339. http://dx.doi.org/10.1080/01904160701554997

[2] Fageria, N.K., Baligar, V.C. and Jones, C.A. (2011) Growth and Mineral Nutrition of Field Crops. 3rd Edition, CRC Press, Boca Raton. http://dx.doi.org/10.1201/b10160 
[3] Goedert, W.J. (1983) Management of the Cerrado Soils of Brazil: A Review. Journal of Soil Science, 34, 405-428. http://dx.doi.org/10.1111/j.1365-2389.1983.tb01045.x

[4] Hitsuda, K., Toriyama, K., Subbarao G.V. and Ito, O. (2010) Percent Relative Cumulative Frequency Approach to Determine Micronutrient Deficiencies in Soybean. Soil Science Society of America Journal, 74, 2196-2210. http://dx.doi.org/10.2136/sssaj2010.0158

[5] Lopes, A.S. and Cox, F.R. (1977) A Survey of the Fertility Status of Surface Soils Under “Cerrado” Vegetation in Brazil. Soil Science Society of America Journal, 41, 742-747. http://dx.doi.org/10.2136/sssaj1977.03615995004100040026x

[6] Fageria, N.K., Baligar, V.C. and Clark, R.B. (2002) Micronutrients in Crop Production. Advances in Agronomy, 77, 185-268. http://dx.doi.org/10.1016/S0065-2113(02)77015-6

[7] N. K. Fageria and V. C. Baligar (1997) Response of Common Bean, Upland Rice, Corn, Wheat, and Soybean to Soil Fertility of an Oxisol. Journal of Plant Nutrition, 20, 1279-1289. http://dx.doi.org/10.1080/01904169709365335

[8] EMBRAPA (Empresa Brasileira de Pesquisa Agropecuaria) (1979) Manual de Métodos de Análise de Solo (Manual and Methods of Soil Analysis). Centro Nacional de Pesquisa de Solos, Rio de Janeiro, Brazil. http://www.agencia.cnptia.embrapa.br/Repositorio/Manual+de+Metodos

[9] da Silva, F. C. (1999) Manual de Analyses Químicas de Solos, Plantas e Fertilizantes (Manual of Chemical Analysis of Soils, Plants and Fertilizers). Embrapa Informação Tecnológica, Brasilia/Rio de Janeiro, Brazil.

[10] Fageria, N.K., Baligar, V.C. and Li, Y.C. (2009) Differential Soil Acidity Tolerance of Tropical Legume Cover Crops. Communications in Soil Science and Plant Analysis, 40, 1148-1160. http://dx.doi.org/10.1080/00103620902754127

[11] Fageria, N.K. (2001) Adequate and Toxic Levels of Copper and Manganese in Upland Rice, Common Bean, Corn, Soybean, and Wheat Grown on an Oxisol. Communications in Soil Science and Plant Analysis, 32, 1659-1676. http://dx.doi.org/10.1081/CSS-100104220

[12] Fageria, N. K. (2002) Influence of Micronutrients on Dry Matter Yield and Interaction with Other Nutrients in Annual Crops. Pesquisa Agropecuaria Brasileira, 37, 1765-1772. http://dx.doi.org/10.1590/S0100-204X2002001200013

[13] Lucas, R.E. and Knezek, B.D. (1972) Climatic and Soil Conditions Promoting Micronutrient Deficiencies in Plants. In: J. J. Mortvedt, F. R. Cox, L. M. Shuman and R. M. Welch, Eds., Micronutrients in Agriculture, Soil Science Society of America, Madison, 265-288.

[14] Fageria, N.K. and Baligar, V.C. (2002) Micronutrients' Influence on Root Growth of Upland Rice, Common Bean, Corn, Wheat, and Soybean. Journal of Plant Nutrition, 25, 613-622. http://dx.doi.org/10.1081/PLN-120003385

[15] Fageria, N.K. (2008) The Use of Nutrients in Crop Plants. CRC Press, Boca Raton. http://dx.doi.org/10.1201/9781420075113.ch1

[16] Fageria, N.K. and Moreira, A. (2011) The Role of Mineral Nutrition on Root Growth of Crop Plants. Advances in Agronomy, 110, 251-331. http://dx.doi.org/10.1016/B978-0-12-385531-2.00004-9

[17] Fageria, N.K. (1992) Maximizing Crop Yields. Marcel Dekker, Inc., New York.

[18] Sainju, U.M., Singh, B.P. and Whitehead, W.F. (2005) Tillage, Cover Crops and Nitrogen Fertilization Effects on Cotton and Sorghum Root Biomass, Carbon, and Nitrogen. Agronomy Journal, 97, 1279-1290. http://dx.doi.org/10.2134/agronj2004.0213

[19] Fageria, N.K., Baligar, V.C. and Bailey, B.A. (2005) Role of Cover Crops in Improving Soil and Row Crop Productivity. Communications in Soil Science and Plant Analysis, 36, 2733-2757. http://dx.doi.org/10.1080/00103620500303939

[20] Fageria, N.K. (2007) Green Manuring in Crop Production. Journal of Plant Nutrition, 30, 691-719. http://dx.doi.org/10.1080/01904160701289529

[21] Baligar, V.C., Fageria, N.K., Paiva, A.Q., Silveira, A., Pomella, A.W.V. and Machado, R.C.R. (2006) Light Intensity Effects on Growth and Micronutrient Uptake by Tropical Legume Cover Crops. Journal of Plant Nutrition, 29, 19591974. http://dx.doi.org/10.1080/01904160600927633

[22] Tang, C. and Rengel, Z. (2003) Role of Plant Cation/Anion Uptake Ratio in Soil Acidification. In: Z. Rengel, Ed., Handbook of Soil Acidity, Marcel Dekker, Inc., New York, 57-81. http://dx.doi.org/10.1201/9780203912317.ch3

[23] Barber, S.A. (1984) Liming Materials and Practices. In: F. Adams, Ed., Soil Acidity and Liming, 2nd edition, America Society of Agronomy, Crop Science Society of America, Soil Science Society of America, Madison, 171-209. http://dx.doi.org/10.2134/agronmonogr12.2ed.c4

[24] Mengel, K., Kirkby, E. A., Kosegarten, H. and Appel, T. (2001) Principles of Plant Nutrition. 5th Edition, Kluwer Academic Publishers, Dordrecht. http://dx.doi.org/10.1007/978-94-010-1009-2

[25] Brady, N.C. and Weil, R.R. (2002) The Nature and Properties of Soils. 13th Edition, Prentice-Hall, Upper Saddle River. 